\title{
Role of Two- Dimensional Speckle Tracking Strain versus Conventional Echocardiography in the Assessments of Left Ventricular Systolic Function in Middle-aged Hypertensive Patients.
}

\author{
DOI: https://doi.org/10.32007/89330-38 \\ Mahasen M. Abd Al-Majeed * \\ Najeeb H. Mohammed** \\ Ghazi F. Haji****
}

\author{
MBChB, DDV, MSc \\ MBChB, DM, MSc, PhD \\ FICMS
}

\section{J Fac Med Baghdad 2019; Vol.61, No.1 Received : April 2019 Accepted : July 2019 Published: July 2019}

Background: Global longitudinal strain (GLS) echocardiography is a new technique that can be used to detect an early left ventricular dysfunction in various heart diseases. Systemic hypertension is a major risk factor for cardiovascular accidents. The early managementof its complication on the heart plays an important role in the outcome of the disease. Hypertension is associated with changes in several aspects of left ventricular structure, function, and systolic strains. Various echocardiographic techniques are used to evaluate left ventricular function in hypertensive patients.

Objectives: To evaluate the effectiveness of speckle tracking global left ventricular strain percentage (GLVS\%)in the assessments of left ventricular systolic function in comparison to conventional echocardiography in middle-aged hypertensive patients.

Patients and Methods: The study was conducted from December 2017 till November 2018 at the Department of Echocardiography and Catheterization / Baghdad Teaching Hospital - Medical City, Baghdad, Iraq. One hundred and four hypertensive patients classified as; group I that involved patients with reversed E/A ratio on PW Doppler with reversed Pulsed Wave (PW) tissue Doppler study and group II with patients having normal E/A ratio on PW Doppler and reversed E prime/A prime on PW tissue Doppler study. The control (group III) recruited from the relative of the patients included 104 sex and age-matched healthy individuals. A detailed history with the recommended investigations and blood pressure measurements was performed for all participants. Additionally, echocardiography examination was implemented using standard methods, considering left ventricle (LV) internal dimension, LV ejection fraction percentage (LV EF\%), LV diastolic function using PW Doppler and lateral mitral annular tissue Doppler, S prime, Mitral annular plane systolic excursion (MAPSE) and global LV speckle tracking strain percentage (GLVS\%).

Results: Group I included 76 patients with a mean age of (48 \pm 6.6 years) and group II included 28 patients with a mean age of (48 \pm 6.6 years). All the participants had normal EF\% $(>60 \%)$, MAPSE (> $13 \mathrm{~mm})$, and $\mathrm{S}$ prime $(>9 \mathrm{~cm} / \mathrm{sec}$ ) while there were a significantly decreased GLVS $\%$ in the diseased groups in comparison to the control one $(\mathrm{P}<0.005)$ being less in group II $(-14 \pm 1 \%)$ than in Group I $(-$ $16 \pm 1 \%)$. In addition to a significant negative linear correlation between GLVS\% with that of pulse pressure and IVST respectively $(\mathrm{p}=0.04)$ and with that of $\mathrm{E} / \mathrm{A}$ ratio and $\mathrm{E} / \mathrm{E}$ prime ratio $(\mathrm{p}=0.001)$.

Conclusions: GLVS\% is a better method in the assessment of LV systolic function in in middle-aged hypertensive patients than conventional echo methods since it could detect an early impairment in LV systolic function despite preserved LV systolic function measured by the conventional echo methods.

Keywords: Systemic hypertension; Tissue Doppler Imaging; Speckle tracking echocardiography.

\begin{tabular}{l} 
Introduction: \\
Hypertension is a major risk factor for cardiovascular \\
diseases with high morbidity and mortality as it \\
increases the heart work $(1,2)$. \\
\hline * Dept. of Physiology, College of Medicine, $A L$ - \\
Iraqia University. Correspondence email: \\
Mahasen_Abdulmajeed@aliraqia.edu.iq \\
**Dept. of Physiology, College of Medicine, \\
University of \\
Dr._najeebalmously@yahoo.com \\
***Dept. of Medicine, College of Medicine, \\
University of \\
Ghazi_haji@comed.uobaghdad.edu.iq
\end{tabular}

\section{Introduction:}

Hypertension is a major risk factor for cardiovascular increases the heart work $(1,2)$.

* Dept. of Physiology, College of Medicine, $A L$ raqia University Correspondence email Mahasen_Abdulmajeed@aliraqia.edu.iq
Systemic pressure overload causes different changes in longitudinal, radial and circumferential mechanics of the heart (3). In addition to mechanical changes, systolic and diastolic functions are significantly affected in patients with systemic hypertension (4). Echocardiography is a non-invasive most widely used diagnostic test in cardiology, which is also safe and accurate in the diagnosis of cardiac diseases in all ages even in pregnant and fetal life $(1,5)$. Although echocardiography is a second-line study in the evaluation of hypertensive patients, it is a valuable, easily reproducible tool to give clue impression about 
LV geometry, systolic and diastolic changes. Left ventricular ejection fraction percentage (LV EF\%) represents the global result of both longitudinal and circumferential contraction; it provides only an indirect estimate of myocardial contractile function and does not measure it directly. Second, it is readily influenced by a number of factors including loading conditions, heart rate, etc. Third, and the most important, it is not sensitive enough to detect subtle changes in the contractile function and therefore not suitable for detecting subclinical myocardial damage (1). Mitral annular plane systolic excursion (MAPSE) has been suggested as a parameter for left ventricular (LV) systolic function which reflects LV longitudinal function and thus provides complementary information to $\mathrm{EF} \%$. Moreover, reduced MAPSE could be used as a sensitive early marker of LV systolic dysfunction in hypertensive patients with normal EF, where compensatory increased circumferential deformation might mask the reduced longitudinal deformation (6).

In Tissue Doppler Imaging (TDI) the S prime velocity waveforms which correspond to the peak systolic contraction velocity correlates well with global LV function even though it is very much preloaddependent (7). Echocardiographic strain imaging is an innovative approach recently developed for the assessment of LV myocardial mechanics, an angleindependent technique, because it tracks deformation between acoustic markers in the ultrasonic image in two dimensions and employs automated algorithms to analyze temporal variations (frame to frame) in the mobility of acoustic speckle markers of 20-40 pixels' size along different spatial orientations. Strain is the percentage change in the length of a myocardial segment during a given period of time and has a unit of $\%$. As the myocardium shortens during systole, the strain has a negative value but when there is stretch or lengthening of the myocardium, the strain becomes positive. The gray-scale image on echocardiography is composed of several bright speckles that are produced as a result of the scatter of the ultrasound beam by the tissue. The STE software identifies these speckles and then tracks them frame-by-frame using a 'sum-of-the absolute ifferences' algorithm. From this data, the software automatically resolves the magnitude of myocardial deformation in different directions and generates strain $(8,9)$. This study aimed to Correlate the effectiveness of speckle tracking echocardiography using global left ventricular strain percentage (GLVS\%) with the conventional echocardiography in the assessments of LV systolic function in middle-aged hypertensive patients.

\section{Patients and Methods:}

This study was performed from December 2017 till November 2018 at the Department of Echocardiography and Catheterization / Baghdad Teaching Hospital - Medical City, Baghdad, Iraq. One hundred and four patients with essential(primary) hypertension with an age range from 35 to 55 years of both sexes were included. These patients were categorized into two groups; group I patients on Pulsed Wave Doppler (PWD) with reversed $\mathrm{E} / \mathrm{A}$ ratio and reversed Eprime/Aprime ratio on PW tissue Doppler image (TDI), and group II patients with normal E/A ratio on PWD and reversed Eprime / Aprime ratio on PW by TDI. One hundred and four sex and age-matched healthy individuals were recruited from the relative of the patients as a control group III. Patients with ischemic heart disease, diabetes mellitus, renal failure, primary pulmonary disease, valvular heart diseases, thyroid diseases, hyperlipidemia, SLE, atrial fibrillation, obesity, cardiomyopathy, infiltrative cardiac disease, current and history of heavy smoking and those with poor quality echocardiographic images were excluded. All individuals received written information and gave informed consent.

Medical history, ECG, CXR, investigations that are required to exclude the diseases in the exclusion criteria were done. Measurements and calculation of $\mathrm{BMI}$ and BSA. Blood pressure were taken according to the American College of Cardiology (ACC) and American Heart Association (AHA) guideline for blood pressure measurements (10) using Rossmax MG150f Digital sphygmomanometer.

Echocardiography was done including standard 2-D and Doppler studies according to standardized protocol of American Society of Echocardiography (ASE) and the European Association of Echocardiography recommendations 2015 using a 3.5 $\mathrm{MHz}$ transducer with available equipment (Philips CX 50 ultrasound, USA machine). The Interventricular septum (IVSd) and left ventricle posterior wall measurements were calculated from the standard left parasternal long axis view at the end of diastole. Left ventricle (LV) internal dimension during systole and diastole were carefully obtained in the 2D-guided M-mode echocardiography then according to the Teichholz M-mode formula the LV ejection fraction $\%$ was calculated by the machine software as shown in figure $1(11,12)$.

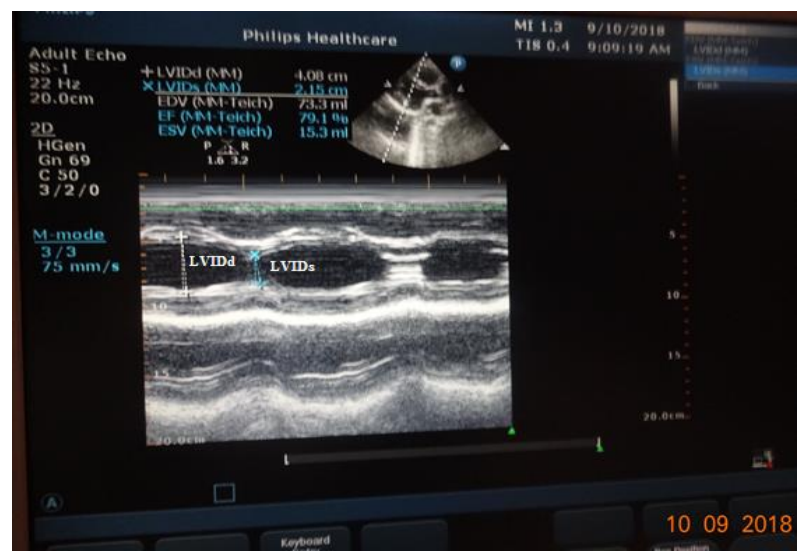

Figure 1: M-mode guided by 2-D echocardiography for LV EF\% calculation. 
LV mass index (LVMI) and Relative wall thickness (RWT) were then calculated. LV geometry was classified according to the presence or absence of LV hypertrophy defined by an LVM index as accepted by the ASE and the European Association of Cardiovascular classification (13).

Mitral annular plane systolic excursion (MAPSE) was measured in the M-mode while the cursor was placed to the junction of mitral valve (MV) plane with the free wall of the left ventricle (LV) as shown in figure 2 (14).

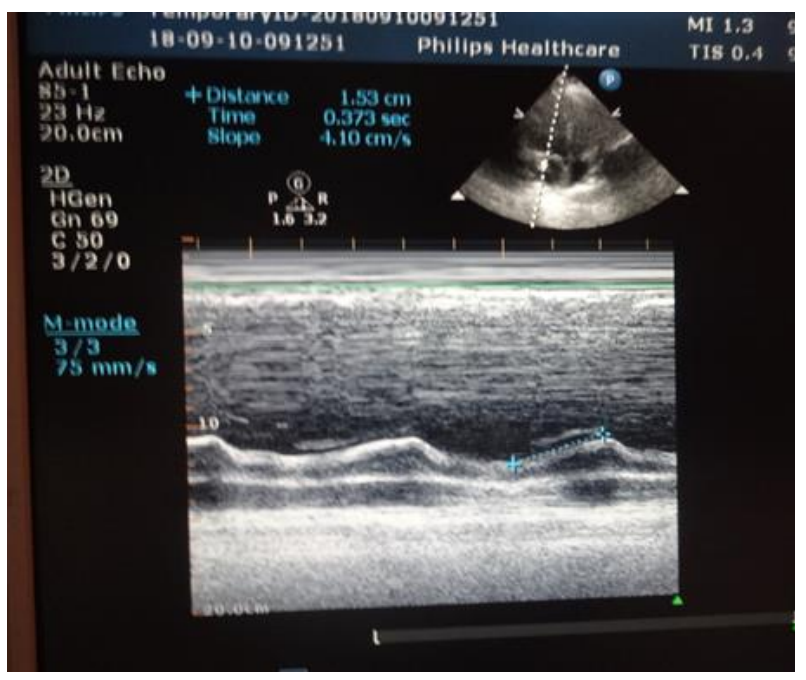

Figure 2: Mitral annular plane systolic excursion measurement.

Transmitral PWD was obtained at the mitral leaflet tips, the peak early (E), late (A) diastolic filling velocities and $\mathrm{E} / \mathrm{A}$ ratio were recorded (15). TDI with the PWD sample volume placed at the lateral mitral annulus was used to measure the initial first negative (E prime) and a late positive ( $\mathrm{S}$ prime) wave velocities as shown in figure $3(16)$.

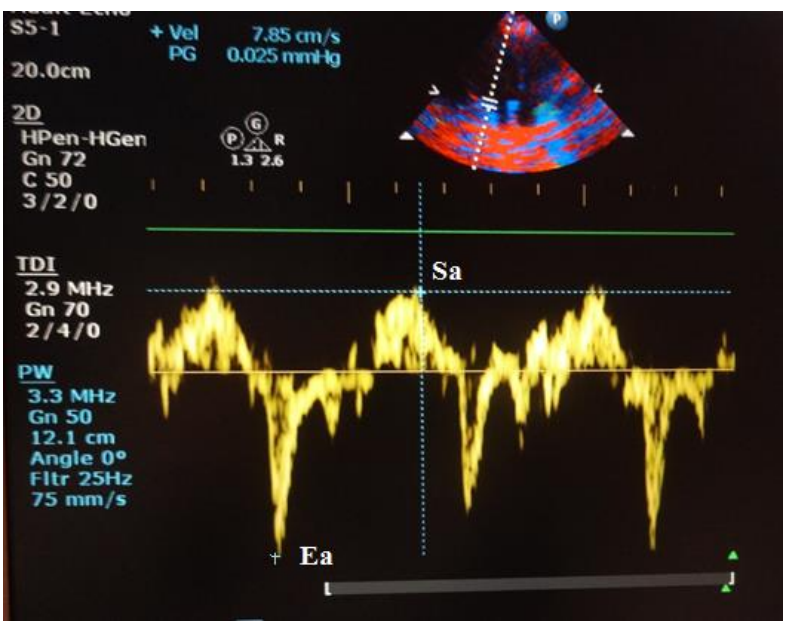

Figure 3: PW tissue Doppler imaging for measuring $S$ prime velocity.

Additionally, LV Speckle-tracking echocardiography was obtained from apical four, three and twochamber views during stable ECG recording and end- expiratory breath-hold using an offline QLAB-CMQ software program (17). The three-point-and-click method used manually adjustments the region of interest was then done. After that, the software divides the LV myocardium into six parts and generates global longitudinal strain calculated for each view then the global Bull's eye shows an 8segmental model with averaged global longitudinal strain \%. However, the average of three consecutive cardiac cycles was recorded as a strain value as shown in figures 4 and 5(18).

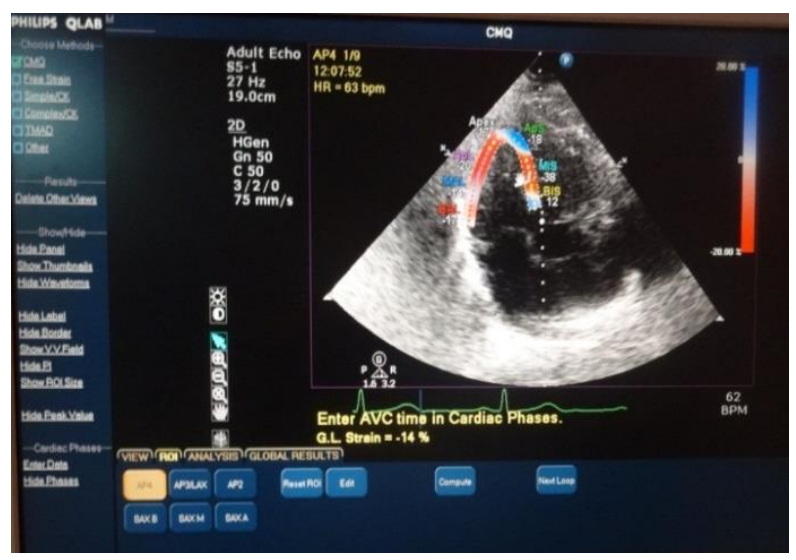

Figure 4: Global LV Strain in 4-chamber view.

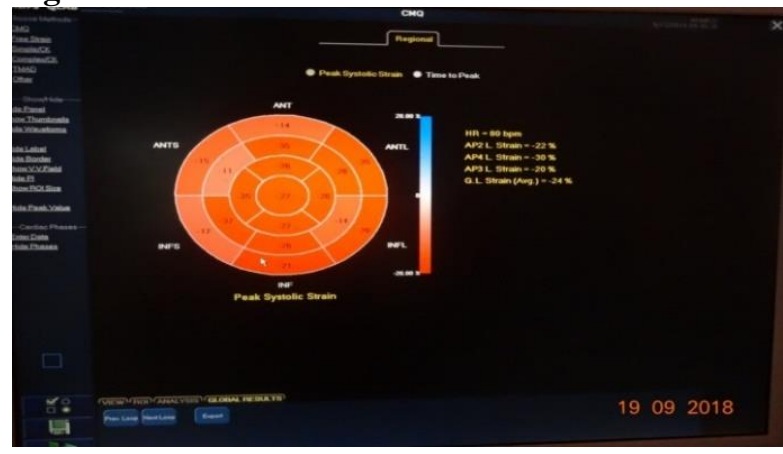

Figure 5: Global longitudinal LV Strain \%.

\section{Statistical Analysis:}

In this case-control study, data was analyzed using SPSS version 20 for windows. For all tests, a probability value (P-value) of $\leq 0.05$ was considered to be statistically significant. Normally distributed data were presented as mean \pm SD for continuous variables. Statistical comparisons among more than two groups were carried out by one-way analysis of variance (ANOVA). Pearson's correlation coefficient (r) was used to test the correlation.

\section{Results:}

The studied sample with a mean age of $48 \pm 6.6$ years was categorized into three groups according to Doppler studies as:

Group I: Included 76 (73\%) systemic hypertensive patients of either sex; 44 women and 32 men with reversed E/A ratio on PW Doppler and reversed E prime /A prime ratio on PW tissue Doppler with a mean age of $48.41 \pm 6.36$ years.

Group II: Included 28 (27\%) systemic hypertensive patients of either sex; 17 women and 11 men with normal A ratio on PW Doppler and reversed E 
prime/A prime ratio on PW tissue Doppler with a mean age of $49.38 \pm 5.32$ years.

Group III: Included 104 healthy subjects of either sex; 41 men and 63 women with normal Doppler study served as a control group with a mean age of $48.92 \pm$ 6.03years.
The characteristics and demographic data of the studied groups are shown in Table 1, which demonstrates that they were age, BMI and BSA matched groups $(\mathrm{P}>0.05)$.

Table 1: Anthropometric measurements and blood pressure parameters of the studied groups.

\begin{tabular}{lllllll}
\hline Variables & $\begin{array}{l}\text { Group I } \\
\mathrm{n}=76\end{array}$ & $\begin{array}{l}\text { Group II } \\
\mathrm{n}=28\end{array}$ & $\begin{array}{l}\text { Group III } \\
\mathrm{n}=104\end{array}$ & $\begin{array}{l}\text { GIvs. } \\
\text { GIII } \\
\text { P value }\end{array}$ & $\begin{array}{l}\text { GIIvs. } \\
\text { GIII } \\
\text { P value }\end{array}$ & $\begin{array}{l}\text { GI vs. } \\
\text { GII } \\
\text { P value }\end{array}$ \\
\hline Age (years) & $48 \pm 7$ & $48 \pm 6$ & $48 \pm 7$ & 0.845 & 0.936 & 0.759 \\
\hline BMI $\left(\mathrm{Kg} / \mathrm{m}^{2}\right)$ & $26.9 \pm 1.5$ & $26.8 \pm 0.7$ & $26.9 \pm 1.3$ & 1.000 & 0.998 & 1.000 \\
\hline BSA $\left(\mathrm{m}^{2}\right)$ & $1.84 \pm 0.12$ & $1.79 \pm 0.07$ & $1.84 \pm 0.1$ & 0.765 & 0.789 & 0.985
\end{tabular}

*BMI= Body Mass Index, BAS= Body surface area.

Table 2 shows that there was a significant difference between the diseased groups regarding the duration of hypertension $((\mathrm{P}=0.005)$ with a longer disease duration in Group II $(9.5 \pm 4.23$ years $)$ while it was (6.5 \pm 4years) in Group I. There was a higher percentage of uncontrolled hypertension in Group II $(89.1 \%)$ than in Group I $(69.7 \%)$. A significant difference was found between the studied groups in respect to their systolic blood pressure and pulse pressure being higher in group II with mean systolic blood pressure of $(158 \pm 15) \mathrm{mmHg}$ and a mean pulse pressure of $(69 \pm 10) \mathrm{mmHg}$. However, the diastolic blood pressure results show a significant difference between the diseased and the control groups, with the mean reported in group II $(89 \pm 9) \mathrm{mmHg}$.

Table 2: Blood pressure parameters of the studied groups.

\begin{tabular}{lllllll}
\hline Variables & $\begin{array}{l}\text { Group I } \\
\mathrm{n}=76\end{array}$ & $\begin{array}{l}\text { Group II } \\
\mathrm{n}=28\end{array}$ & $\begin{array}{l}\text { Group III } \\
\mathrm{n}=104\end{array}$ & $\begin{array}{l}\text { GI vs. } \\
\text { GIII } \\
\text { P value }\end{array}$ & $\begin{array}{l}\text { GII vs. } \\
\text { GIII } \\
\text { P value }\end{array}$ & $\begin{array}{l}\text { GI vs. } \\
\text { GII } \\
\text { P value }\end{array}$ \\
\hline $\begin{array}{l}\text { Disease duration } \\
\text { (years) }\end{array}$ & $6.5 \pm 4.23$ & $9.5 \pm 4.23$ & $\ldots \ldots$ & $\ldots \ldots$ & $\cdots \cdots$ & 0.005 \\
\hline Systolic Bp (mmHg) & $151 \pm 16$ & $158 \pm 15$ & $117 \pm 5$ & $0.001^{*}$ & $0.001^{*}$ & $0.033^{*}$ \\
\hline Diastolic Bp (mmHg) & $88 \pm 8$ & $89 \pm 9$ & $74 \pm 7$ & $0.001^{*}$ & $0.001^{*}$ & 0.984 \\
\hline $\begin{array}{l}\text { Pulse pressure } \\
\text { (mmHg) }\end{array}$ & $61 \pm 12$ & $69 \pm 10$ & $40 \pm 3$ & $0.001^{*}$ & $0.001^{*}$ & $0.001^{*}$ \\
\hline Uncontrolled Bp \% & 69.7 & 89.1 & & & & \\
\hline
\end{tabular}

$* \mathrm{Bp}=$ blood pressure.

Table 3 demonstrates a significant difference $(\mathrm{P}<$ $0.05)$ between all groups regarding IVST, PWT, and RWT being the largest thickness in Group II. While there was a significant difference $(\mathrm{P}<0.05)$ in the LV internal dimensions and volumes (LVIDd, LVIDs, and LVEDV) with the least volume reported in group II (105 \pm 28$) \mathrm{ml}$. The largest mass index was found in the same group (group II). Moreover, LVH was reported in all patients in Group II in addition to a maximum septal thickness was recorded in group II $(1.2 \pm 0.2 \mathrm{~cm})$. LVH was reported only in $(71 \%)$ of patient in Group I. However, the only type of geometrical changes in LV in both diseased groups was of concentric hypertrophy

Table 3: Left ventricular geometrical parameters of the studied groups.

\begin{tabular}{|c|c|c|c|c|c|c|}
\hline Variables & $\begin{array}{l}\text { Group I } \\
\mathrm{n}=76\end{array}$ & $\begin{array}{l}\text { Group II } \\
\mathrm{n}=28\end{array}$ & $\begin{array}{l}\text { Group III } \\
\mathrm{n}=104\end{array}$ & $\begin{array}{l}\text { GIvs. } \\
\text { GIII } \\
\text { P value }\end{array}$ & $\begin{array}{l}\text { GIIvs. } \\
\text { GIII } \\
\text { P value }\end{array}$ & $\begin{array}{l}\text { GI vs. } \\
\text { GII } \\
\text { P value }\end{array}$ \\
\hline LVIDd $(\mathrm{cm})$ & $3.4 \pm 2.1$ & $3.5 \pm 2.1$ & $4.4 \pm 3.4$ & $0.001 *$ & $0.001 *$ & 0.994 \\
\hline LVIDs (cm) & $2.2 \pm 1.3$ & $1.9 \pm 1.3$ & $3.5 \pm 0.6$ & $0.001 *$ & $0.001 *$ & 0.751 \\
\hline IVST (cm) & $1.1 \pm$ & $1.2 \pm 0.2$ & $0.77 \pm$ & $0.001^{*}$ & $0.001 *$ & $0.005^{*}$ \\
\hline PWT $(\mathrm{cm})$ & $1.02 \pm$ & $1.1 \pm 0.2$ & $0.74 \pm$ & $0.001^{*}$ & $0.001^{*}$ & $0.001^{*}$ \\
\hline LVEDV (ml) & $108 \pm 26$ & $105 \pm 28$ & $125 \pm 7$ & $0.001^{*}$ & $0.001 *$ & 0.548 \\
\hline LVESV (ml) & $31 \pm 15$ & $36 \pm 14$ & $38 \pm 9$ & 0.627 & $0.016^{*}$ & 0.587 \\
\hline RWT(cm) & $0.48 \pm 0.09$ & $0.51 \pm 0.06$ & $0.34 \pm 0.07$ & $0.001^{*}$ & $0.001 *$ & $0.006^{*}$ \\
\hline LVMI $(\mathrm{g} / \mathrm{m} 2)$ & $79 \pm 18$ & $88 \pm 19$ & $42 \pm 6$ & $0.001^{*}$ & $0.001 *$ & 0.998 \\
\hline LVH\% & $71 \%$ & $100 \%$ & $0 \%$ & & & \\
\hline
\end{tabular}

- $\quad$ LVIDd = Left Ventricular Internal Dimensions during diastole, LVIDs= Left Ventricular Internal Dimensions during systole, IVST=inter ventricular septum thickness, PWT = posterior wall thickness, LVEDV= 
Left Ventricular End Diastolic Volume and LVESV= Left Ventricular End Systolic Volume, RWT= Relative wall thickness, LVMI = Left Ventricular mass index, LVH=left ventricular hypertrophy.

Table 4 demonstrates the LV function. Regarding the diastolic LV function, the table validates that the peak E velocity was significantly decreased in the diseased groups being the least velocity in group I $(72 \pm 14)$ $\mathrm{cm} / \mathrm{sec}$ while there was a significant decrease in the $\mathrm{E}$ prime velocity being the least velocity in group II (6.6 $\pm 1.19) \mathrm{cm} / \mathrm{sec}$. In addition, there was a significant increase in the $\mathrm{E} / \mathrm{E}$ prime ratio noticed in the diseased groups being the highest ratio in group II $(15.3 \pm$ 0.99 ). The table shows the LV systolic function to be within normal values in respect to conventional methods with the significant differences being between the diseased groups and the control one regarding left ventricle LV EF\% being higher in group II (68ะ 9\%). Furthermore, the $\mathrm{S}$ prime measurement shows no significant difference $(\mathrm{P}>$ 0.05 ) between the studied groups with results recorded being more than $11 \mathrm{~cm} / \mathrm{sec}$ in all groups. Moreover, regarding the last conventional methode which was MAPSE measurement show that there was no significant difference $(P>0.05)$ between the studied groups with results recorded being more than $12 \mathrm{~mm}$ in all studied groups. Howeve, global LV speckle tracking measurement shows a significant difference $(\mathrm{P}<0.05)$ between the diseased groups in comparison to controls with the GLVS\% being ( $-14 \pm$ $1 \%)$ in group II and $(-16 \pm 1)$ in group I while it was $(-21.9 \pm 1)$ in the control group.

Table 4: Left ventricular function parameters of the studied groups.

\begin{tabular}{lllllll}
\hline Variables & $\begin{array}{l}\text { Group I } \\
\mathrm{n}=76\end{array}$ & $\begin{array}{l}\text { Group II } \\
\mathrm{n}=28\end{array}$ & $\begin{array}{l}\text { Group III } \\
\mathrm{n}=104\end{array}$ & $\begin{array}{l}\text { GIvs. } \\
\text { GIII } \\
\text { P value }\end{array}$ & $\begin{array}{l}\text { GIIvs. } \\
\text { GIII } \\
\text { P value }\end{array}$ & $\begin{array}{l}\text { GIvs. } \\
\text { GII } \\
\text { P value }\end{array}$ \\
\hline $\mathrm{E}(\mathrm{cm} / \mathrm{s})$ & $72 \pm 14$ & $94 \pm 17$ & $107 \pm 7$ & $0.001^{*}$ & $0.001^{*}$ & $0.001^{*}$ \\
\hline $\mathrm{A}(\mathrm{cm} / \mathrm{s})$ & $85 \pm 13$ & $79 \pm 25$ & $74 \pm 6$ & $0.001^{*}$ & $0.001^{*}$ & 0.107 \\
\hline E/A & $0.65 \pm 2.8$ & $1.75 \pm 1.3$ & $1.5 \pm 2.1$ & $0.001^{*}$ & $0.001^{*}$ & $0.001^{*}$ \\
\hline E prime (cm/s) & $6.89 \pm 1.96$ & $6.6 \pm 1.19$ & $12.6 \pm 1.45$ & $0.001^{*}$ & $0.001^{*}$ & $0.001^{*}$ \\
\hline E/ E prime & $8.06 \pm 1.76$ & $15.3 \pm 0.99$ & $6.97 \pm 0.38$ & $0.001^{*}$ & $0.001^{*}$ & $0.001^{*}$ \\
\hline LV EF\% & $66 \pm 8$ & $68 \pm 9$ & $61 \pm 1$ & $0.001^{*}$ & $0.001^{*}$ & 0.895 \\
\hline $\begin{array}{l}\text { MAPSE } \\
(\mathrm{mm})\end{array}$ & $15 \pm 1$ & $13 \pm 1$ & $17 \pm 2$ & $0.029^{*}$ & $0.001^{*}$ & 0.084 \\
\hline $\begin{array}{l}\mathrm{S} \text { prime } \\
\text { (cm/sec) }\end{array}$ & $9 \pm 1.2$ & $8.7 \pm 1.3$ & $10.1 \pm 2.1$ & $0.001^{*}$ & $0.001^{*}$ & 0.999 \\
\hline GLVS $\%$ & $-16 \pm 1$ & $-14 \pm 1$ & $-22 \pm 1$ & $0.001^{*}$ & $0.001^{*}$ & $0.001^{*}$ \\
\hline
\end{tabular}

- $\quad$ LVEF\% =Left ventricular Ejection Fraction percentage, MAPSE= Mitral annular plane systolic excursion and GLVS\% = Global longitudinal ventricular strain percentage.

Linear regression using Person correlation shows a significant negative linear correlation between GLVS\% with that of pulse pressure and IVST respectively $(\mathrm{r}=-0.25, \mathrm{p}=0.015)(\mathrm{r}=-0.22, \mathrm{p}=0.04)$.

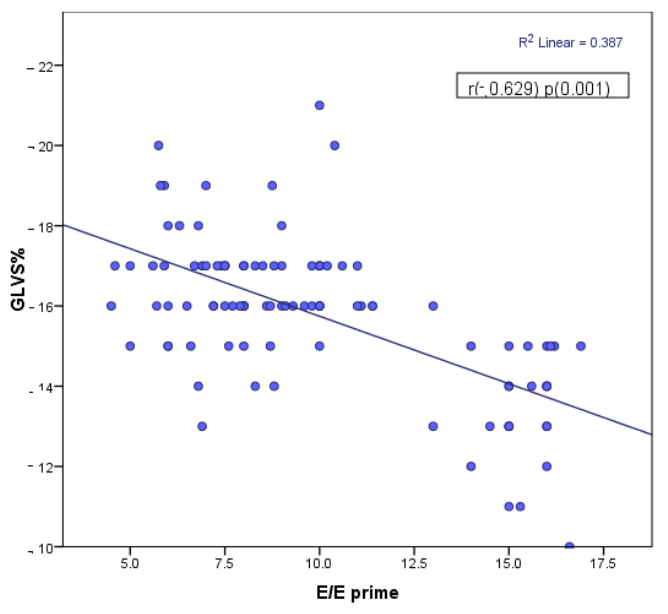

Figure 1: Correlation between GLVS and E/E prime.
The results show a highly significant high negative linear correlation between GLVS\% with the of E/A ratio and $\mathrm{E} / \mathrm{E}$ prime ratio respectively $(\mathrm{r}=-0.629, \mathrm{p}=$ $0.001)$ and $(r=-0.62, p=0.001)$.

\section{Discussion:}

The mean systolic and diastolic blood pressure values are in similar to those reported by Muataz et al. and $\mathrm{Xu}$ et al $(2,19)$ but are higher than those of Maryam et al being higher in this study (20). These differences may be related to that most of the patients in the current study are with uncontrolled blood pressure was $(69.7 \%$ of group I and $89.1 \%$ of group II). The RWT is a marker of adverse hypertensive effect on the heart for a long-standing time (21). The estimated RWT of the LV in our study revealed that there was only concentric LVH was seen in all patients in group II and $71 \%$ of the patients in group I. This can be explained by the observation that those patients have the highest blood pressure that adversely affects cardiac structure and results in LVH which is a maladaptive response to chronic pressure overload. These results are in concordance with Elmasry et al. and Mizuguchi Y et al. $(22,23)$ but not in agreement with Izzo et al. (24) which found that all 
the patients developed LVH. This may be attributed to the younger age of our study group and the exclusion of those of with risk factors like diabetes mellitus, obesity, and coronary artery diseases. This current study revealed a normal LV systolic function measured by MAPSE and tissue Doppler by measuring $\mathrm{S}$ prime velocity. The slightly higher reading of EF\% reported in group II $(68 \pm 9 \%)$ is in agreement with the studies of Sharief K. M. et al., Salam et al. and W.A.I. Hamed et al. $(25,26,27)$ in which the LVH might be attributed to the explanation of higher EF\%.

Diastolic dysfunction can happen in hypertensive patients before systolic dysfunction, which may be due to a noncompliant hypertrophic LV even without obvious signs of heart failure $(25,28)$. Moreover, delayed LV relaxation with the resultant increased early diastolic pressure, and a reduced transmitral pressure gradient explains the reversed E/A ratio and normal TDI study in group I patients, while in group II patients, the results revealed a higher E velocity and $\mathrm{E} / \mathrm{E}$ prime ratio due to further deterioration of diastolic function and impedance to atrial emptying. These differences in the LV diastolic function may be related to hypertension that affects LV compliance and decreases in relaxation of the LV. Additionally, the longer duration of hypertension that exacerbates the deterioration in the diastolic function where the duration of hypertension in group II is $(9.5 \pm 4 \mathrm{y})$ while in group $I$ is $(6.5 \pm 4 y)$. This finding is in agrreement with those of Vijaykumar, Ting-Yan $\mathrm{Xu}$ et al. and Shantanu et al. $(29,19,30)$. Speckle Tracking Echocardiography is an imaging technique that is used to analyze the tissue motion in the heart by using the naturally occurring myocardial speckle pattern when imaged by ultrasound (31). In respect to global GLVS \%, our results demonstrated a reduced global LV longitudinal strain which reflects early changes in systolic function in hypertensive patients being less in group II $(-14 \pm 1 \%)$ than to group I $(-16 \pm 1 \%)$. However, the global GLVS\% was reduced despite the normal conventional echo parameters (EF\%, MAPSE, and S prime measurements). This finding goes in parallel with those of W.Hamed et al. Amal et al. , Kraigher et al. Jun et al. and Minatoguchi S.et al. findings $(27,32,33,34,35)$. Kraigher et al demonstrates lower GLVS\% in heart failure with preserved $\mathrm{EF} \%$ and in hypertensive patients compared to normal group whereas the others demonstrated impaired systolic function in hypertensive patients using GLVS\% with normal EF\%. Correlation analysis revealed a significant negative linear correlation between GLVS\% with that of pulse pressure and IVST pulse pressure in addition to high negative linear correlations between GLVS\% with that of E/A ratio and E/E prime ratio. This can be explained by increased pulse pressure, with the more hypertrophied ventricle with the resultant increased filling pressure of the LV leading to more deterioration in diastolic function with the resultant worsted GLVS\%.

Conclusion:
Global left ventricular strain percentage (GLVS\%) is a better method in the assessment of LV systolic function in in middle-aged hypertensive patients than conventional echo methods since it can detect an early impairment in LV systolic function despite preserved LV systolic function measured by the conventional echo methods.

\section{Authors contributions:}

Study conception, Critical revision and design: Najeeb Hassan Mohammed and Ghazi Farhan Haji (supervisors).

Acquisition of data analysis, Drafting of manuscript and Interpretation of data: Mahasen Mohammed Abd Al-Majeed, Najeeb Hassan Mohammed and Ghazi Farhan Haji.

\section{Reference}

1. Lee JH and Park JH. Role of echocardiography in clinical hypertension. ClinHypertensv. 2015;21:9.https://doi.org/10.1186/s40885-0150015-8

2. Hussein MF, Al-Kadi RGW and Zaki. AS Detection of the Early Cardiac changes of hypertension by Echocardiography. Fac Med Baghdad.2009; $\quad$ 51(2): 123 126.http://iqjmc.net/article/241

3. Enar SC.The Role of Echocardiography in Hypertension.JClinExpCardiolog .2016; 7:12. doi:10.4172/2155-9880.1000486.

4. Knezevic B, Music L, Batricevic G, Bulatovic N, Nenezic A, Vujovic J, et al. The Impact of Risk Factors on the Diastolic Dysfunction in Patients with Hypertension. Insights in Blood Pressure.2016; 2(2):13. doi: 10.21767/2471-9897.1000013.

5. Raheem SA, Haji GF. Foetal Echocardiography: A Novel Method for Detecting Congenital Heart Disease. Journal of Clinical and Diagnostic Research. $2019 ; 13(2): \quad$ 22-24.DOI: 10.7860/JCDR/2019/38300.12607.

6. Hu K, Liu D, Herrmann S, Niemann M, Gaudron $P D$, Voelker Wet al. Clinical implication of mitral annular plane systolic excursion for patients with cardiovascular disease. European Heart Journal Cardiovascular Imaging. 2013; 14: 205-212.doi: 10.1093/ehjci/jes240.

7. Chengode S. Left ventricular global systolic function assessment by echocardiography. Ann Card Anaesth. 2016;19:S26-34.doi: 10.4103/09719784.192617

8. Gunasekaran P, Panaich S, Briasoulis

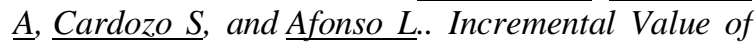
Two Dimensional Speckle Tracking Echocardiography in the Functional Assessment and Characterization of Subclinical Left Ventricular Dysfunction. CurrCardiol Rev. 2017; 13(1): 3240.doi: 10.2174/1573403X12666160712095938.

9. Bansal M, Kasliwal RR. How do I do it? Speckletracking echocardiography. Indian Heart J. 2013 Jan; 65(1): 117-123. doi: 10.1016/j.ihj.2012.12.004 
10.Blonsky R, Pohl M, Nally JV, Thomas JG. 2017 ACC/AHA hypertension guidelines: Toward tighter control.Cleveland Clinic Journal of Medicine. 2018;85(10):771-778.doi:10.3949/ccjm.85a.18028

11.Lang RM, Badano LP, Mor-Avi V, Afilalo J, Armstrong A, Ernande et al. Recommendations for cardiac chamber quantification by echocardiography in adults: an update from the American Society of Echocardiography and the European Association of Cardiovascular Imaging. LJ Am Soc Echocardiogr. 2015 Jan;28(1):1-39.e14. doi: 10.1016.

12.Abd Al-Majeed MM, Mohammed NH and Al Saffar HB. Relation of the Ankle Brachial Index (ABI) to left ventricularsystolic function in patients with coronary artery disease.J Fac Med Baghdad .2015; 57(1):45-49.http://iqjimc.net/article/168

13. Paoletti E, De Nicola L, Gabbai FB, Paolo Chiodini, Maura Ravera, Laura Pieracci, et al. Associations of Left Ventricular Hypertrophy and Geometry with Adverse Outcomes in Patients with CKD and Hypertension. Clin J Am SocNephrol. 2016; 11(2): 271-279. doi: 10.2215/CJN.06980615

14.Terada T, Mori K, Inoue $M$ and Yasunobu $H$. Mitral annular plane systolic excursion/left ventricular length (MAPSE/L) as a simple index for assessing left ventricular longitudinal function in children. Echocardiography. 2016;33(11): 1703170922. https://doi.org/10.1111/echo.13325

15. Nagueh SF, Smiseth OA, Appleton CP, Byrd BF, Dokainish H, Edvardsen Tet al. Recommendations for the Evaluation of Left Ventricular Diastolic Function by Echocardiography: An Update from the American Society of Echocardiography and the European Association of Cardiovascular Imaging. J Am SocEchocardiogr. 2016; 29:277-314. doi: 10.1016/j.echo.2016.01.011.

16. Mogelvang R, Biering-Sфrensen T and Jensen JS. Tissue Doppler echocardiography predicts acute myocardial infarction, heart failure, and cardiovascular death in the general population. European Heart Journal - Cardiovascular Imaging, Volume 16, Issue 12, December 2015, Pages 13311337,https://doi.org/10.1093/ehjci/jev180.

17. Gan GCH, Ferkh A, Boyd A and Thomas L. Left atrial function: evaluation by strain analysis. CardiovascDiagnTher 2018; $\quad$ 8(1):2946.doi: $10.21037 /$ cdt.2017.06.08

18. Castel A, Menet A, Ennezat P, François Delelisa, Caroline Le Goffica, Camille Binda et al. Global longitudinal strain software upgrade:Implications for intervendor consistency and longitudinal imaging studies. Archives of Cardiovascular Disease. 2016; 109:

22

30.https://doi.org/10.1016/j.acvd.2015.08.006

19.Xu T, Sun JP, Lee AP, Yang XS, Ji L, Zhang Z, Li $Y$, et al. Left Atrial Function as Assessed by SpeckleTracking Echocardiography in Hypertension. Medicine. 2015; 94(6)18.doi: 10.1097/MD.0000000000000526

20. Eghbali M, Khosravi A, Feizi A, Mansouri A, Mahaki $B$ and Sarrafzadegan N. Prevalence, awareness, treatment, control, and risk factors of hypertension among adults: a cross-sectional study in Iran. Epidemiol Health 2018May; vol 40pag 19. doi: $10.4178 /$ epih.e2018020

21.Tawfeeq HA, Al-Omary HL and Haji GF. The impact of systemic hypertension-related heart remodeling on right ventricle mechanics: A twodimensional echocardiographic speckle trackingstudy.Int. J. Res. Pharma.Sci., 2018;9(4):15671571.DOI: https://doi.org/10.26452/ijrps.v9i4.17722 22.Elmasry TM, Abd-Elbary MF, Marghany KA, and Abo-Elmagd MS. The Effect of Left Ventricular Geometry on Myocardial Performance Index in Hypertensive Patients. J ClinExpCardiolog. 2018;9: 570. DOI: $10.4172 / 2155-9880.1000567$

23. Mizuguchi $Y$, Oishi $Y$, Miyoshi H, Iuchi $A$ and Nagase N. Concentric left ventricular hypertrophy brings deterioration of systolic longitudinal, circumferential and radial myocardial deformation in hypertensive patients with preserved left ventricular pump function.JCardiol.2010;55(1):2333.DOI: https://doi.org/10.1016/j.jjcc.2009.07.006

24. Izzo R, Losi M, Stabile E, Mai Tone, Lönnebakken , Grazia Canciello , Giovanni Esposito et al. Development of Left Ventricular Hypertrophy in Treated Hypertensive Outpatients Hypertension: The Campania Salute Network. 2017; 69:136142. http://www.clinicaltrials.gov. Unique identifier: NCT02211365.

25. Sharief KM, Hassan HA, Osman H, Al-Safi A. Ejection Fraction Rate for Hypertensive Patients Using Echocardiography. Med. Res. Chron., 2015, 2 (3), 322-329.

26.Mahdi SA, Mohammed NH and AL-Saffar HB. The effect of Valsalva maneuver on diastolic filling indices in patients with essential hypertension. Fac Med Baghdad.2010; $52 \quad$ (1): 13 18.https://www.iasj.net/iasj?func=issueTOC\&isId= 1332\&uiLanguage $=$ en

27. Hamed WAI, Kamal AM, Noamany MF, Soliman MA and Abdel Ra'ouf MM. Evaluation of left ventricular performance in hypertensive patients by speckle tracking echocardiography: Correlation with brain natriuretic peptide. The Egyptian Heart Journal. 2014; 66, 299308.https://cyberleninka.org/article/n/544616

28.Al Zubeidy ZA, Al Qaseer A, Ridha AF. Assessment Of Diastolic Function In Diabetic Patients Using

Conventional Echocardiogram \& Tissue Doppler Imaging.Mustansiriya Medical Journal.2017;16 (1):34-

44.https://www.iasj.net/iasj?func=issueTOC\&isId= 7491 \&uiLanguage $=$ en

29. Ingle VV. Study of diastolic dysfunction in essential hypertension patients in relation to age and duration of treatment. Ingle VV. Int J Adv Med. 2017; 4(5):1447-1450.http://dx.doi.org/10.18203/23493933.ijam20174301

30. Sengupta SP, Caracciolo G, Thompson C, Abe H and Sengupta PP. Early impairment of left 
ventricular function in patients with systemic hypertension: New insights with 2-dimensional speckle tracking echocardiography. Indian heart journal (2013) 65:48 $\quad-5$ 2.doi: 10.1016/j.ihj.2012.12.009

31.Hussein MF, Mahmood HN and Essa SI. The Value of Longitudinal Strain versus Coronary Angiography inDetection of Coronary Artery Disease.European Journal of General Medicine.2018;1(1): 2-7.

32.Ayoub AM, Keddeas VW, Ali YA, and El Okl RA. Subclinical LV Dysfunction Detection Using Speckle Tracking Echocardiography in Hypertensive Patients with Preserved LV Ejection Fraction. Clin Med Insights Cardiol. 2016; 10: 8590.https://doi.org/10.4137/CMC.S38407

33. Kraigher-Krainer E, Shah AM, Gupta DK, Santos A, Claggett B, Pieske B, et al.. Impaired systolic function by strain imaging in heart failure with preserved ejection fraction. $\mathrm{J}$ Am CollCardiol. 2014;63(5):447-56.doi: 10.1016/j.jacc.2013.09.052.
34.Huang J, Yan Z, Rui Y, Fan L, Shen D and Chen D. Left Ventricular Systolic Function Changes in Primary Hypertension Patients Detected by the Strain of Different Myocardium Layers. Medicine (Baltimore). 2016; 95(2): 2440.doi: 10.1097/MD.0000000000002440. 35.Minatoguchi S, Kawasaki M, Tanaka $R$, Yoshizane T, Ono K, Saeki $M$ et al. Evaluation of systolic and diastolic properties of hypertensive heart failure using speckle-tracking echocardiography with high volume rates. Heart Vessels. 2017 Oct;32(10):1202-1213. doi: 10.1007/s00380-0170995-2. Epub 2017 Jun 21. 
دور تقنية التباع النقطي ثنائي الابعاد مقارنة بصدى القلب التقليدي في تقييم الوظيفة الانقباضية للبطين الايسر لاى مرضى ارتفاع ضغط الام الثرياني

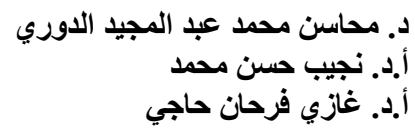

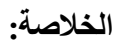

خلفية البحث:ارتفاع ضغط الدم الثرياني يشكل احد عوامل الخطورة لجهاز القلب و الدور ان.العلاج المبكر للمرض له دور مهم في تقليل المضاعفات

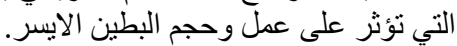
الاهداف:تقييم الوظيفة الانقباضية للبطين الإيسربتقنية التتباع النقطي ثناي الابعاد مقارنة بصدى القلب التقليدي

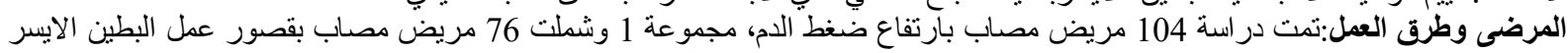

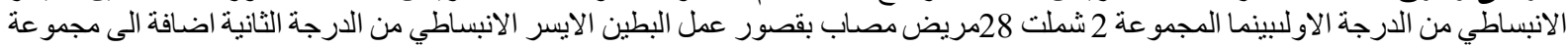

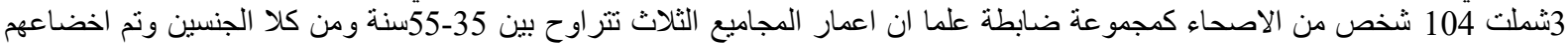

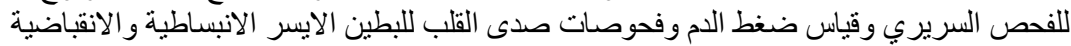

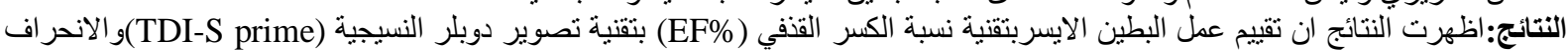

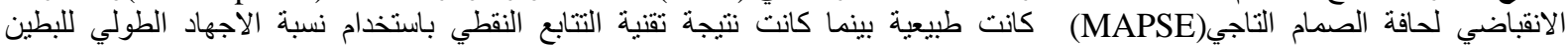

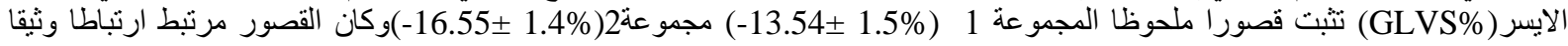

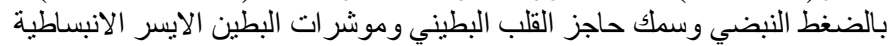

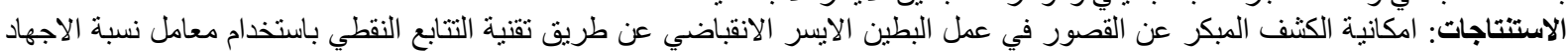

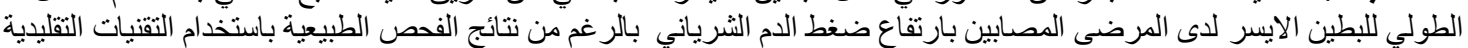
مفتاح الكلمات:ارتفاع ضغط الدم الثنرياني،تقنية التتابع النقطي، تقنتية تصوير دوبلر النسيجية 